This is an Accepted Manuscript of an article published by Taylor \& Francis in Politics, Religion \& Ideology on 27 Feb 2020, available online: http://

www.tandfonline.com/10.1080/21567689.2020.1732935 


\title{
Religious Freedom in a Secular Human Rights Order
}

\begin{abstract}
This paper examines the problems associated with conceptualizing religious freedom within a human rights order that remains indebted to secular principles. It considers the theological-political premises of the modern secular State, the function of religious tolerance as a liberal-democratic discourse, how political subjectivity is constructed through the concepts of freedom and equality, and the inequality inherent in the secular vehicle of the neutral public sphere. It suggests that the potential for human rights law to protect religious difference lies in understanding the theological-political bias in secularism and renegotiating the relationship between religious pluralism and democratic principles.
\end{abstract}

\section{Introduction}

'We cannot adopt a rationalist definition of freedom - thus claiming universality - and simultaneously make a pluralist society the place of its flowering and its exercise. A universalist doctrine evolves ineluctably toward a model equivalent to the one-party state'. ${ }^{1}$ Claude Lèvi-Strauss' comment is generally regarded as a pointed criticism of the conception of liberty under the influence of universal humanism, one that has served the liberal-democratic State and its invention of human rights. ${ }^{2}$ It calls into question not merely the universal basis for humanism, but also the inhibiting effect of the formal ontological principle of freedom - and

\footnotetext{
* The author extends his gratitude to the anonymous referees for their salient and insightful comments on the draft of this article.

${ }^{1}$ Claude Lèvi-Strauss, The View from Afar, translated by Joachim Neugroschel and Phoebe Hoss (New York: Basic Books, 1985), p. 70.

${ }^{2}$ See, for example, Tzvetan Todorov, 'Lèvi-Strauss,' in Mark Lilla (ed) New French Thought:

Political Philosophy (Princeton, New Jersey: Princeton university Press, 1994), p. 46.
} 
its corollary, the natural equality of human beings - on a society characterised by cultural coexistence. If religion is one of the principal and enduring manifestations of cultural differentiation, the function of religious freedom in a pluralistic society cannot be realized without challenging the premises of liberal humanism. Any attempt to reconcile the tension between respect for religious difference and liberal-humanistic values inevitably comes up against the principle of secularism, as both an ideological discourse and a political technique for regulating the place of religion in the public space. In this sense, the state of religious freedom in the modern State cannot be appreciated without consideration of the intertwined role of secularism.

At the same time, the apparent conflict between religious freedom and secularism can no longer merely be seen as a reflection of the historical duality between the theological and the political. As Stathis Gourgouris observes, '[t]heir trajectory in Western (essentially Christian) thought has moved from the initial tension between realms of the sacred (theological) and the profane (political) to an association between them that leaves no bounds for interpretation privileging one term over another according to specific historical needs'. ${ }^{3}$ What is required, therefore, is a more sensitive hermeneutical approach concerned with disinterring both the elements of the sacred that survive in the political, and how the discourse of secularism operates to reinstate the theological-political bias upon which it is founded, often at the expense of the protection of the free expression of religious difference.

\section{Secularism as a Theological-Political Paradigm}

In The Kingdom and the Glory Giorgio Agamben begins his theological genealogy of economy and government by commenting on Carl Schmitt's thesis that '[a]ll significant concepts of the

\footnotetext{
${ }^{3}$ Stathis Gourgouris, Lessons in Secular Criticism (New York: Fordham University Press, 2013), p. 121.
} 
modern theory of the state are secularized theological concepts'. ${ }^{4}$ For Agamben, Schmitt's thesis proposes that there is more than a mere conceptual identity between theology and modern political concepts; rather, secularization serves as a signature that refers back to a historical process that is principally theological: 'as a specific performance of Christian faith that, for the first time, opens the world to man in its worldliness and historicity', the secularization of the world becomes a mark of its belonging to a divine economy (oikonomia). ${ }^{5}$ Underwriting the distinction between power and its exercise, Kingdom and Government, the divine economy manifests itself in various institutions and modalities of secular power, including the division of powers at the heart of democratic political theory - Schmitt's 'legislative State', the State under the rule of law, in which the acts of government are impersonal and circumscribed by a prescribed legal framework, may be seen as the result of the 'providential paradigm' in which Kingdom and Government, legitimacy and legality, coincide. ${ }^{6}$ The dual structure of the theological governmental machine operates in the modern age through the distinction between legislative or sovereign power and executive or governmental power, according to which the State legislates in a transcendent and universal way, while it executes with particularity the providential dictates through which free individuals are bound to immanent causes. ${ }^{7} \mathrm{We}$ need not take Agamben's ontology of governmentality any further to appreciate the consequences of such a perspective: not only does it bring into relief the extent of the indebtedness of modern secular government to the economic notion of government bestowed by Christian theology, it suggests that the secular theory of democratic governance remains indelibly marked by a

\footnotetext{
${ }^{4}$ Carl Schmitt, Political Theology: Four Chapters on the Concept of Sovereignty, transl. G. Schwab (Chicago: Chicago University Press, 2005), p. 36; cited in Giorgio Agamben, The Kingdom and the Glory: For a Theological Genealogy of Economy and Government (Homo Sacer II, 2), transl. Lorenzo Chiesa (Stanford, California: Stanford University Press, 2011), p. 2.

${ }^{5}$ Agamben, op. cit., p. 4.

${ }^{6}$ Ibid., p. 136.

${ }^{7}$ Ibid., p. 142.
} 
strategic theological-political, and indeed providential-economical, relation whose legacy performs a constitutive role in the modern State.

We can identify a number of features of this theological-political relation relevant to the historical evolvement of secularism. The first concerns the conditions of possibility for a secularized religion; in other words, what made it possible for the mystery of divine Being to be accessible through the lens of human ontology, displacing the archaic relation to the unknowable? There is little scope here to delve into the precise structures and events through which Christian theology developed a theory about itself as a corpus of religious doctrines, ethics and practices; it suffices to point out that the very technique of self-reflexivity, of Christianity holding up a mirror to itself and subjecting itself to critique moderated by external (that is, non-religious) perspectives, remains a pivotal element of the secularization process peculiar to Western Christianity. As Gil Anidjar explains, the distinction between the 'religious' and the 'secular' was a systemic invention of Christianity - in attempting to liberate itself, to extricate itself from its own conditions, it turned itself into an object of criticism, judging and naming itself, demanding its own transcendence, reincarnating itself as secular. ${ }^{8}$ Following the logic of Michel Foucault's analysis of the Christian investment in sexuality, Anidjar argues that secularism is 'part of a discourse of power and of institutions that are bent on making us invest religion, making us cathect it...making us know or recognize religion for what it is... and mostly, for what it is not: Christianity, secularized' ${ }^{9}$ In other words, religious and secular are not merely interdependent signifiers, each deriving its meaning from the other; secularism has emerged as a political doctrine precisely through a Christian conception of temporal authority, and the concepts of religion and religious belief are tied to a particular

\footnotetext{
${ }^{8}$ Gil Anidjar, 'Secularism', Critical Inquiry, 33 (2006), pp. 52-77, at p. 60.

${ }^{9}$ Ibid., pp. 61-62.
} 
epistemology and particular practices intrinsic to Christianity's institutionalization within the domains of law and politics.

A second feature concerns the humanistic conceptualization of the human-divine relationship, whose historical trajectory has run parallel to and been inextricably linked with the discursive technique of Christian self-critique. In his seminal political history of religion Marcel Gauchet suggests the transformative significance of the appearance of the State for the development of Christianity. There is a political emancipation associated with the intellectual reformulation of the divine function in human affairs, whereby the distancing and separation of the absolute subject opens the space for the rational comprehension of God's difference. This dynamic of transcendence revolves around a fundamental caesura between religious immanence (a relationship with the 'ineffable Other') and the postulate of human subjectivity having access to rational divine purposes. If Protestantism emphasized the tension between the human subject who possesses individual autonomy and his ever-increasing dependence on God through predestination and grace, it was principally to the end of demonstrating the impossibility of reconciling the two positions and rendering 'the logic of otherness explicit' ${ }^{10}$ Secularism, far from being a reaction against religion, is the product of this religious transcendence, which is to say that, rather than a 'conflict between being inside or outside religion, between the God of Faith and godless reason', reason progresses through God, ${ }^{11}$ with religion being the contested site of the human subject's inwardly critical gaze. The 'societal or collective form of religious transcendence, the institutionalized religion that determined the outlook of society, has vanished', ${ }^{12}$ only to make possible the secular reality of individual 'immanent transcendence'. For Gauchet, the modern State is the culmination of this process of

\footnotetext{
${ }^{10}$ Marcel Gauchet, The Disenchantment of the World: A Political History of Religion, transl. Oscar Burge (Princeton: Princeton University Press, 1997), fn. 12, p. 211.

${ }^{11}$ Ibid., pp. 61-62.

${ }^{12}$ Andre Cloots, Stijn Latrè and Guido Vanheeswijck, 'The Future of the Christian Past: Marcel Gauchet and Charles Taylor on the Essence of Religion and its Evolution', The Heythrop Journal, LVI (2015), pp. 959-974, at pp. 967-968.
} 
disenchantment with the world, the result of a 'two-thousand-year process of surreptitiously reducing otherness by the dynamic process of making God different' and allowing human actors to 'gain access to the mastery of their collective destiny'. ${ }^{13}$

At the same time, the humanization of the divine, characteristic of the emergence of secular humanism in Europe at least since the Eighteenth century, has as its correlate and intersecting movement the divinization of the human. ${ }^{14}$ The disposition of sacredness from the exteriority of revelation to the interiority of the human soul is first and foremost a hermeneutical problem: without the existence of a 'metalanguage' through which meaning and value in the world may be determined, religion is reduced to an experiential product of human conscience. This would align with Friedrich Nietzsche's criticism of transcendent values, that judgments of value concerning life are undermined by the impossibility of human beings, who clearly belong to life, adopting an external position. ${ }^{15}$ As Luc Ferry reads this radical humanism, it amounts to suggesting that sacredness is nothing more than a disguised form of collective conscience, since '[t]he illusions of transcendence are born when we project outside ourselves what in reality is only an unconscious part of ourselves'. ${ }^{16}$ The mark of a humanism of 'man made god', then, is the justification of a universal ethics - in itself a sacred kind of transcendence which underlies a common bond - that would take the form of an alternative metaphysical worldview, a metaphysics of subjectivity. We can find some elements of the groundwork for this alternative metaphysics in Immanuel Kant's critique of religion. For Kant, Christianity is in essence a (indeed the only) moral religion: it operates under the basic principle that each person is bound to strive to become a better person through divine assistance, where such assistance is predicated upon the person knowing what he must do in

\footnotetext{
${ }^{13}$ Gauchet, op. cit., p. 59.

${ }^{14}$ See Luc Ferry, Man Made God: The Meaning of Life, transl. David Pellauer (Chicago and London: The University of Chicago Press, 2002).

${ }^{15}$ See Friedrich Nietzsche, The Twilight of the Idols, in The Portable Nietzsche, transl. Walter Kaufmann (New York: Viking Press, 1968), p. 474.

${ }^{16}$ Ferry, Man Made God, op. cit., p. 133.
} 
other to be worthy of the assistance. In this sense, moral religion is a 'reflective' faith, in contrast to a 'dogmatic' faith that depends upon historical revelation; it privileges the power of 'good will' to access knowledge, and thus accords with the rationality of practical reason. ${ }^{17}$ The concept of reflective faith explains the intrinsic connection between Christianity and pure morality. The individual's moral duty, which the categorical imperative endorses as an unconditional universality, can be interpreted through the principle that we ought to act as though God had abandoned us. As Jacques Derrida perceptively puts it,

In enabling us to think (but also to suspend in theory) the existence of God, the freedom or the immortality of the soul, the union of virtue and happiness, the concept of 'postulate' of practical reason guarantees this radical dissociation and assumes ultimately rational and philosophical responsibility, the consequences here in this world, in experience, of this abandonment. ${ }^{18}$

Given this logic of morality, in which morality is accessible purely through practical reason, the moral religion of Christianity effectively announces the death of God and stages the individual's alienation from religious cosmology. However, therein lies the aporia involved in purifying universal reason - and its moral and political products - from all religiosity, as Kant implicitly acknowledges in the construct of 'reflective faith'. It is an aporia which re-emerges in a different guise in the philosophy of German Romanticism, which attempts to resolve the paradox by reconciling religion with the collective unconscious, and locating the true source of individuality in the 'synthesis of a concrete particularity with the universal'. ${ }^{19}$ Romanticism's response is to call for the secularization of faith and the divinization of the nation and the people. This political appropriation of faith would divert human ontology away

\footnotetext{
${ }^{17}$ Immanuel Kant, Religion Within the Limits of Reason Alone, transl. Theodore M. Greene and Hoyt H. Hudson (New York: Harper \& Row, 1960), Book I section 4.

${ }^{18}$ Jacques Derrida, 'Faith and Knowledge: The Two Sources of 'Religion' at the Limits of Reason Alone', in Gil Anidjar (ed) Acts of Religion (New York and London: Routledge, 2002), p. 51. ${ }^{19}$ Luc Ferry, Homo Aestheticus: The Invention of Taste in the Democratic Age, transl. Robert De Loaiza (Chicago and London: University of Chicago Press, 1993), p. 261.
} 
from the formal rational model, opening up new critical methods in naturalism and historicism, all the while rendering the religious element of life dependent upon the individual's political destiny. 'From that point forward, the salvation of the individual rests in the hands of political forces'. ${ }^{20}$

\section{Religious Tolerance and Liberal-Democratic Pluralism, a Holy Alliance}

At the heart of modern secularism is the relationship between the particularity of religion and the subjectivization of political freedom under democratic principles. 'Tolerance' is the name given to the principle vehicle for mediating this relationship. Derrida notes that 'tolerance' is intrinsic to Christian morality: '[i]t was printed, emitted, transmitted and circulated in the name of the Christian faith and would hardly be without relation to the rise, it too Christian, of what Kant calls "reflecting faith" - and of pure morality as that which is distinctively Christian'. ${ }^{21}$ What, then, does this reveal about the role of the discourse on religious tolerance in promoting secularist values? We can attempt a response by deconstructing two ideological functions of the concept of 'tolerance': as an ethical-political principle for regulating cultural particularity; and as a mechanism for depoliticising religion in the context of a pluralistic society.

\section{Tolerance and cultural particularity}

Let us take up a line of argument critiquing the regulation of cultural particularity proposed by Slavoj Žižek, namely that tolerance is the ideological tool of liberal multiculturalism, operating to culturalize politics: '[p]olitical differences, differences conditioned by political inequality, economic exploitation, and so on, are naturalized and neutralized into cultural differences, different ways of life, which are something that cannot be overcome, but must merely be

\footnotetext{
${ }^{20}$ Blandine Kriegel, The State and the Rule of Law, transl. Marc A. LePain and Jeffrey C. Cohen (Princeton, New Jersey: Princeton University Press, 1995), p. 134.

${ }^{21}$ Derrida, 'Faith and Knowledge,' op. cit., p. 59.
} 
tolerated' ${ }^{22}$ The culturalization of politics is one consequence of the fact that within the liberal political model the individual is bound to and defined by opposing forces, namely the universal and the particular. Whereas the individual as a rationally moral entity is conceived as universal (on this point we can draw directly from the consequences of Kantian universal reason), thus fundamentally capable of being abstracted from his or her lifeworld, at the same time he or she is born within and survives through a particular cultural environment. Liberalism manages this opposition through the distinction between the public and private realms: the universal subject acts in public, with all the ramifications of this species of identity (including formal equality and political agency), while cultural particularity is effectively privatized, as a set of parochial beliefs and practices associated with the family, ethnic clan and society. Within this schema, tolerance is the privileged attitude of the universal-rational subject, whose extraction from culture overcomes the latter's introverted barbarism and myopic intolerance. However, to fully appreciate the ideological stakes involved in the separation of the universal-political-public from the particular-cultural-private sphere we must go beyond the Marxist critique demonstrating how the abstract universal subject masks a set of concrete economic and political conditions; what is further required is the converse enquiry - '[h]ow and in what specific historical conditions does abstract universality itself become a "fact of (social) life"? ${ }^{23}$ Which is to say, how do individuals, who are always caught up in a social environment governed by culturally-specific norms, experience themselves as universal subjects, and ultimately as subjects of universal human rights?

It would be prosaic to suggest that, just as liberalism belongs to a defined historical milieu specific to the development of the European State, the liberal notion of tolerance is itself a product of this environment and its thinking. More arresting is the fact that, far from

\footnotetext{
${ }^{22}$ Slavoj Žižek, 'Tolerance as an Ideological Category', Critical Inquiry, 34 (2008), pp. 660-682, at p. 660.

${ }^{23}$ Slavoj Žižek, Violence: Six Sideways Reflections (London: Profile Books, 2008), p. 127.
} 
dispassionately serving the requirements of pluralism and the inevitable cultural compromise that the secular State must negotiate, tolerance is a discourse that privileges culturally-specific relations among individuals and between individuals and the State, relations largely shaped by Western Christianity. As Teresa Bejan observes, toleration emerged in the early modern period as one possible response to the collapse of the concordia of Christendom, which saw the 'advent of competing and conscientiously uncivil, evangelical, and schismatic Protestantisms in a transforming and expanding public sphere. ${ }^{24}$ The modern understanding of liberal toleration, and the particular institutional arrangements it has favoured - including the separation of Church and State - should be understood within the broader context of early modern political theory and practice, rather than as a mere reflection of religious conflicts.

As a political gesture, the discourse of toleration acts, in Derrida's terms, 'as a kind of condescending concession', the supplementary mark of sovereignty 'which says to the other from its elevated position, I am letting you be, you are not insufferable, I am leaving you a place in my home, but do not forget that this is my home'. ${ }^{25}$ Toleration carries the dual function of ostensibly withholding judgment - as maintenance of negativity or suspension of condemnation ${ }^{26}$ - while granting permission for the other to appear as itself, albeit conditionally. The condescending concession invokes a structural relationship of subordination, which determines the legitimacy of religion and its expression in accordance with the degree to which its beliefs and customs are faithful to liberal political values. Žižek provides the example of a Muslim woman who wears the veil as a religious practice: where the practice is deemed to result from her adherence to the Islamic faith and pursuant to moral-

\footnotetext{
${ }^{24}$ Teresa Bejan, Mere Civility: disagreement and the limits of toleration (Cambridge MA \& London: Harvard University Press, 2017), p. 49.

${ }^{25}$ Jacques Derrida, 'A Dialogue with Jacques Derrida', in Giovanni Borradori (ed) Philosophy in a Time of Terror: Dialogues with Jurgen Habermas and Jacques Derrida (Chicago and London: University of Chicago Press, 2003), p. 127.

${ }^{26}$ Helen F. Wilson, 'The possibilities of tolerance: intercultural dialogue in a multicultural Europe', Environment and Planning D: Society and Space, 32 (2014), pp. 852-868, at p. 856.
} 
religious precepts, she may be accused of adopting a fundamentalist approach to religious observance (if not being a complicit victim of a patriarchal religious system); on the other hand, where it is understood as an expression of her free choice, the result of her individual sense of spirituality, it effectively loses its religious significance and instead is tolerated as an expression of idiosyncratic individuality. 'What this means is that the subject of a free choice (in the Western tolerant, multicultural sense) can only emerge as the result of an extremely violent process of being torn out of one's particular lifeworld, of being cut from one's roots' ${ }^{27}$ In effect, for the adherent of a minority religion in a secular society, individual free choice entails the transcendence of or departure from one's culture, in which case there is no real choice to act within the culture itself, which is to say, no real freedom to accept, endorse or practice that culture without being drawn into a conflict with the secular order. In the context of multi-cultural norms, then, freedom in the liberal sense is largely illusory, requiring as it does the abrogation of one's culture in so far as it deviates from the Western secularized ideal.

There is another more pervasive sense in which the Christian discourse of toleration reifies an asymmetrical relation between the universal subject and cultural particularism. The way in which universalism itself is understood owes its legacy to Saint Paul's notion of the 'universal', a domain in which there is neither Greek nor Jew, where the exclusivity of the Chosen People is replaced with the inclusivity of all based merely on the categorization of humanity, albeit a humanity conceived in terms of Christian ontology and eschatology. This sets up universality as a site of struggle, the battle between religion as Law (and its supplement sin) and religion as Christ's way of love. Rather than excluding some subjects, as occurs with other religions, Christian universality is formulated from the position of those excluded, for whom there is no specific place within the existing order to which they nonetheless belong. In the process, however, Christianity stages a much more radical exclusion. Christian universality

\footnotetext{
${ }^{27}$ Žižek, 'Tolerance as an Ideological Category', op. cit., p. 663.
} 
is premised upon the sole difference between Christian and non-Christian, a difference which 'cuts across the entire social body, splitting, dividing from within every kind of ethnic identity'. ${ }^{28}$ Thus, the Christian subject, the embodiment of truth, sits in relation to the Jew and the Greek through this divisive mechanism of exclusion; speaking from the perspective of the interminably excluded, the Christian subject pits its universality against the prerogatives and powers of all particular, empirical forms. As Nietzsche expressed it, the Christian 'is a rebel against all privilege by profound instinct - he lives and makes war for ever for "equal rights". ${ }^{29}$ For Paul it is a matter of creating difference from nondifference. Whereas both the Jew and the Greek exist as 'ethnic' subjects, perpetuating particular predicates (genealogy, origin, territory and rituals, among others), Christian universalism declares its differential nondifference through founding the subject as division, which, in contradistinction with the perpetuation of an alternative tradition, 'renders the subjective element adequate to this universality by terminating the predicative particularity of cultural subjects.${ }^{30}$ Of course, it could be contended that the strength of the Pauline notion of universality is precisely the fact that it creates space for respecting differences rather than dissolving them. Alain Badiou takes up this possibility in the penultimate chapter of his philosophical tract on Saint Paul's contribution to universalism. He suggests that the fact that the truth procedure intrinsic to Christianity collapses differences does not entail that the differences should be treated caustically. Given that differences constitute the materiality of the world, the singularity of the subject of truth, tied to the process of becoming universal, penetrates this material by letting the differences be, thus abstaining from moral judgments: '[d]ifferences can be transcended only if benevolence with regard to

\footnotetext{
${ }^{28}$ Slavoj Žižek, 'A Plea for a Return to Diffèrance (with a Minor Pro Domo Sua)', Critical Inquiry, 32 (2006), pp. 226-249, at p. 242.

${ }^{29}$ Friedrich Nietzsche, The Anti-Christ, transl. H. L. Mencken (New York: Alfred A. Knopf, 1924), p. 134.

${ }^{30}$ Alain Badiou, Saint Paul: The Foundation of Universalism, transl. Ray Brassier (Stanford California: Stanford University Press, 2003), p. 57.
} 
customs and opinions presents itself as an indifference that tolerates differences'. ${ }^{31}$ Nonetheless, it is clear from this formulation that tolerating difference is bound up, teleologically at least, with the Christian individual's identity as a universalising subject. Indifferent toleration cannot be other than the transcendence of customary and communitarian differences, which are thereby reduced to their instrumental value for justifying faith in universal humanity. Badiou implicitly acknowledges this when he concludes that the universal can verify its own reality only by recognising in differences their capacity for carrying the universal that 'happens to them like a grace' ${ }^{32}$ In their singularity, differences are without substance, the mere shadows of indifference. In broader terms, the particular is meaningful only insofar as it reveals the universal, and thus betrays its own material, non-essential condition. To tolerate differences is precisely to sit in judgment of what lies outside of the universal.

\section{Depoliticising religion}

Let us turn to the second ideological function of the discourse of toleration, that of depoliticising the religious sphere. As Jurgen Habermas observes, toleration assumes the rejection of the convictions of others - since mere indifference to those convictions would not activate a conflict of truth claims - provided that the rejection is based on a cognitive conflict that does not simply derive from irrational prejudice. Based on the normative consensus of equal treatment and non-discrimination (we shall leave aside the contentious content of these terms, for the time being) adopted within a political community, 'the contradictions that persist at the cognitive level between competing worldviews can be neutralized in the social dimension

\footnotetext{
${ }^{31}$ Ibid., p. 99.

${ }^{32}$ Ibid., p. 106.
} 
of equal treatment'. ${ }^{33}$ It is for this reason that the accommodation of religious plurality has historically tended to serve as a litmus test for the liberalization of the State form, and indeed lead to a secular approach to the philosophical legitimation of the State. Of course, reciprocal religious toleration depends upon 'universally acceptable limits of tolerance', which constitute the shared language of modern democracy. In turn, this imposes a burden on religious communities to adapt their systems of belief to the 'individualistic and egalitarian nature of the laws of the secular community', which necessarily entails that each confession abandons its claim to comprehensively shape the lives of its members. The consequence is 'an imposed depoliticization [of religious doctrines] by redefining, from their internal perspective, the relationships between religious community and (a) the liberal State, (b) other religious communities, and (c) the secularized society'. ${ }^{34}$ For Habermas, this depolitcization is the inevitable cost of living within a pluralistic society whose democratic constitution guarantees cultural differentiation under the condition of political integration. ${ }^{35}$ The idiosyncratic culturalparticular is, in this sense, formally recognized and legally protected by the very mechanism (the constitutional prescription for equal rights) that constrains its dynamism and precludes it from asserting an independent political role. Habermas' thesis on the existence of a cognitive dissonance and the State apparatus for neutralising it suggests that ideological conflict is an inherent part of the democratic polity, one that may be managed through a constitutionallyenforced religious pluralism. However, his insistence on the necessity for a common political culture that would regulate religious life through its subjection to multicultural citizenship, to which religious toleration would give effect, tends to obscure the process by which religion is essentially stripped of its socio-political significance and reduced to the existential category of

\footnotetext{
${ }^{33}$ Jürgen Habermas, 'Intolerance and discrimination', International Journal of Constitutional Law, $1: 1$ (2003), pp. 2-12, at pp. 3-4.

${ }^{34}$ Ibid., p. 6.

${ }^{35}$ Ibid., p. 11.
} 
'bare life'. It also evades the more difficult question of how to define the respective limits of the political and the purely religious, once that artificial opposition is established.

\section{Political Subjectivity and Religious Freedom}

Although secularism does not appear or function in the same way everywhere, there are two constant ideals which define political subjectivity in the secular polity: one is the separation of religion from the State; the other is the equal treatment of religious faiths. As a juridical tool, religious freedom is fundamental to each ideal, albeit in distinct and opposing ways. Before turning to the particular role of human rights in the secular State, it may be worthwhile addressing, in mere outline, certain paradoxes inherent to the concept of freedom. When situated in a historical context they go some way to explaining some of the difficulties associated with how human rights jurisprudence deals with the conflicts between religious freedom and secularism. Jean-Luc Nancy recognizes, as possibly the most fundamental and indelible of paradoxes, that 'freedom cannot present itself without presenting the possibility, inscribed in its essence, of a free renunciation of freedom' ${ }^{36}$ This is an axiomatic point: in its simplest form, freedom includes the freedom to choose to not be free. It is a problem that has long been recognized, particularly in the context of political transitions - ancient Greek philosophers alluded to it when discussing the inherent flaw in the pure conception of democracy, being the ability of a free demos to choose a tyrannical or oligarchical political system to replace democracy, in other words, for the populus to freely vote to deny itself certain future freedoms. However, it has a very specific application when it comes to reconciling religious freedom with the principle of secularism, an application which reveals a number of conflicts. The most obvious one is the conflict of rights and freedoms. Religious freedom, like

\footnotetext{
${ }^{36}$ Jean-Luc Nancy, The Experience of Freedom, transl. Bridget McDonald (Stanford, California: Stanford University Press, 1993), p. 16.
} 
many other institutionally-recognized freedoms, is not absolute, it must be weighed against other necessities and interests, such as public safety, health and morals, which means that the scope or application of the freedom may be restricted - in the context of the freedom to manifest religious belief, this commonly takes the form of legitimately prohibiting expression that is deemed to impinge upon public order (in its particular guise of protecting secularism) or the fundamental rights of others. This is not merely a policy determination, however, it is inherent to the idea of freedom itself, since in its purest conceptual sense it has no discernable limits, which means that where you have multiple freedoms recognized within a political system there will inevitably be overlapping domains and potential conflicts, necessitating the restriction or derogation of one or more freedoms. A second problem is that, as a human right, religious freedom also implies its negative aspect. In other words, freedom of religion includes both the freedom to have a religious belief and the freedom to renounce or avoid religious faith, ${ }^{37} \mathrm{a}$ feature that has ramifications for religious pluralism. For example, when dealing with proselytizing religions, such as Christianity and Islam, for which spreading the faith by converting others is an important facet of their social dimension (even if some established Christian churches no longer formally practice this), it is far from obvious to what extent this religious practice needs to be protected compared with the freedom of the non-religious or minority religions to resist conversion. A further problem lies with the fact that secularist ideology is at least implicitly protected by the same right in its broadest semantic content, namely the freedom of religion, thought and conscience: it is protected both as a non-theistic belief - the expression of individual conscience - but also in the form of freedom from religion. Thus, we have here another potential conflict, in this case between two competing elements of

\footnotetext{
${ }^{37}$ See, for example, Human Rights Committee, General Comment 22, Article 18 (Forty-eighth session, 1993), U.N. Doc. HRI/GEN/1/Rev.1 at 35 (1994), Paragraph 5: 'The Committee observes that the freedom to 'have or to adopt' a religion or belief necessarily entails the freedom to choose a religion or belief, including the right to replace ones current religion or belief with another or to adopt atheistic views...'
} 
the same freedom. The concept of religious freedom, and indeed of human rights more generally, has no intrinsic mechanism for resolving such conflicts, which are therefore left to legal and political interpretive constraints, such as judicial intervention in applying the qualification of whether a restriction is 'necessary in a democratic society'. ${ }^{38}$

A second fundamental paradox, suggested by Zizek, is that belonging to a society involves a point 'at which each of us is ordered to embrace freely, as the result of our choice, what is anyway imposed on us'. ${ }^{39}$ The argument here is quite simple: living within a society already and necessarily involves being subjected to a social order which, no matter the degree of its internal flexibility, prescribes certain normative understandings of what choices can legitimately be made. Every society has a 'complex network of informal rules that tell us how we relate to explicit norms'. ${ }^{40}$ The freedom to choose and decide is always circumscribed within this implicit subjection to the rules guiding our understanding and behaviour. In this sense, the paradoxical element lies in the illusion that the exercise of freedom somehow transcends the norms regulating social relations, in effect, that true freedom operates from a normative tabula rasa. On the one hand, society would not function so effectively without the freedom, since the space for choice and free decision-making underpins civic and personal relationships and is seen as crucial to the functioning of a democratic society; on the other hand, this freedom is largely fictive, because the most pervasive norms that govern our decisions are rarely explicitly acknowledged or accounted for. This is why, for example, arguing that religious precepts that bind women - as based on a fundamentally patriarchal order - violate the freedom of those women in spite of their freely choosing to adopt the practices, misses the point of the problem facing those individuals. It is precisely the sense of 'necessity'

\footnotetext{
${ }^{38}$ A particular qualification prescribed in certain provisions of the European Convention of Human Rights and Fundamental Freedoms - see articles 9, 10 and 11.

39 Žižek, 'Tolerance as an Ideological Category', op. cit., p. 676.

${ }^{40}$ Ibid., p. 675.
} 
associated with the availability and range of choice - the cumulative effect of the norms, conventions and ideologies in that religion and in society more generally, as well as their confluence and conflicts - that needs to be examined. Simply speaking of individual freedom is bound to lead to arguments that run at cross-purposes, since, as we have already observed, the concept of 'freedom' cannot be divorced from the socio-political background that furnishes it with meaning, includes inherent contradictions, and often assumes its own restrictions or derogations. As a regulative concept it always attempts too much, and therefore lacks concrete value in particular social and cultural contexts.

We should attempt to clarify the role of religious freedom in political subjectivity, initially by analysing at the broadly structural level the relationship between religious freedom and political equality, and then by examining how religion itself is a political construct.

\section{Religious freedom and political equality}

It would be uncontentious to suggest that, in a schematic way, the modern democratic process is largely concerned with the distribution of the public and the private, the political and the social; it is an activity that cannot be fully resolved, but ceaselessly works to set the limits of each and minimize their points of conflict. The delimitation of the political and social spheres serves as a theoretical problematic for the polemical struggles involved in the fact of differences and inequalities being conceived through the universalising prism of political equality. On this point we may gain some insights from the analysis of Jacques Rancière, who proposes that the political subject exists in the interval between the names 'man' and 'citizen': as 'a political name, the citizen opposes the rule of equality fixed in law and in principle to the inequalities that characterize "men"” as private individuals, those governed by their particular social and cultural environments; conversely, "the reference to "man" opposes the equal 
capacity of everyone to a privatizations of citizenship'. ${ }^{41}$ This polemical designation of parts and their relations is given political currency through the opposition of the universal to the particular, of political existence to 'bare life'. The political subject is therefore a divided subject, suspended between the logic of self-consciousness, derived from personal, social and cultural identity, and the logic of fundamental political equality. 'Political subjects emerge when the hierarchical order of society is questioned on the basis of radical equality'. ${ }^{42}$ That Rancière conceives of 'equality' as a structural fact of society entails that it is the radical starting point for, rather than the objective of, political action. ${ }^{43}$ A number of consequences follow from this. Firstly, rather than the political and the social designating distinct spheres of life, political equality already exists within social life, since it derives from the universal nature of a human community, and thus operates as the undercurrent that perpetually contests the inequality inherent to social life. The social may be seen as 'the very place where we pose the question of what is social and what is political, what is private, of the order of the individual, or ordinary obscure life, and what is of the order of the public stage, and thereby also of public competence'. ${ }^{44}$ This frame of analysis allows us to appreciate more clearly that the particular organization of the social space that we associate with secularism is also a process for defining and delimiting the manifestation of cultural, private conditions within that space. In this way, religious life is one element of the social sphere which questions the public-private dichotomy, and thereby the political stakes involved in recognising, protecting or restricting it. Secondly, the concept of freedom is constituted as a means of giving effect to equality, to "express the

\footnotetext{
${ }^{41}$ Jacues Rancière, Hatred of Democracy, transl. Steve Corcoran (London and New York: Verso, 2006), pp. 59-60.

${ }^{42}$ Jean-Philippe Deranty, 'Jacques Rancière's Contribution to the Ethics of Recognition', Political Theory, 31:1 (2003), pp. 136-156, at p. 151.

${ }^{43}$ See the critique of this position in Jean-Philippe Deranty, 'Between Honneth and Rancière: Problems and Potentials of a Contemporary Critical Theory of Society', in Katia Genel and JeanPhilippe Deranty (eds) Recognition of Disagreement: A critical Encounter on the Politics of Freedom, Quality, and Identity (New York: Columbia University Press, 2016), p. 69.

${ }^{44}$ Jacues Rancière, The Method of Equality, transl. Julie Rose (Cambridge, UK: Polity, 2016), p. 125.
} 
value of equality as antithetical, radically universalistic opposition to differential, hierarchical treatment'. ${ }^{45}$ Like equality, freedom is treated as a formal concept, without necessarily referring to any one modality or type of liberty. In this context religious freedom creates something of a conundrum: when conceived in terms of the capacity to implement the requirements of equality, freedom is bound to be circumscribed by the norms invested in the civic arrangement of society at any given time, that is, as a function of the rights of citizenship. The type of freedom associated with religious expression would tend to be constrained by radical equality's drive to transcend parochial differences (viewed as inequalities) and thereby stifle the multicultural voices that are meaningful to, and arguably essential for, religious pluralism. The risk for this conception of religious freedom is that it only protects differences that are sanctioned by the requirements of the model of political equality prevalent in the society. In a social environment in which a secular form of civic consensus (regarding speech, expression and publicity) governs the public space given to religious beliefs, there is little to inhibit the influence of the dominant religion and its paradigm of political subjectivity within that consensus. The fact that the secular political order effectively marginalizes religion in the distribution of rights and freedoms tends to render this influence more pronounced.

\section{Religion as a political construct}

This leads us to the epistemological issue of religion as a socio-political construct. Pulling together some of the theoretical threads we have already drawn regarding the theologicalpolitical foundation of secularism, it is apparent that how religion is conceived in the context of pluralistic democracy and human rights discourse, in other words, which aspects of life properly belong to religion and which are to be separated from it, is neither an organic nor a politically neutral determination. A number of commentators have addressed this interpretive

\footnotetext{
${ }^{45}$ Deranty, 'Between Honneth and Rancière', op. cit., p. 67.
} 
question. Kirstie McClure argues for a connection between the modern conceptualization of religion and the development of State governance as a discrete set of practices. She traces the notion of religious freedom (principally through the thought of John Locke) in terms of the civic interest in worldly effects, from which an emergent system of knowledge was deployed to make empirically-based political distinctions between permitted and prohibited practices. In early modern England, the liberal State's concern with the potential harm to the security of the polity and the civil interests of its citizens informed State policy and ideas of social virtue, which in turn redefined tolerance towards religious belief as political judgment based on empirically-verifiable facts. This political epistemology of worldly acts and social practice supports the function of civil authority in regulating the incommensurable articulations of religious truth', and by resolving the 'differences' into 'diversity', 'operates simultaneously to delimit and to empower the state as the sole legitimate adjudicator of worldly practice' ${ }^{46}$

In a different vein, Saba Mahmood analyses the intensification of political interest in religious belief by focusing on the divergent understandings of religious identity and confessional subjectivity. She notes, for example, that the Protestant Christian approach to religious icons and images, in which a subject-object division frames the relationship between the believer and the representative objects (reflecting the theological separation between the personal God and his temporal representation), can be distinguished from the mimetic relationship of intimacy between believer and the Prophet within the tradition of Muslim piety. This difference in religious identity, with its influence on devotional practices, is the source of incompatibility between the formalistic, Christian-inspired laws on blasphemy and the more visceral moral offensiveness of blasphemy in Islam. ${ }^{47}$ This incompatibility helps to explain the

\footnotetext{
${ }^{46}$ Kirstie M. McClure, 'Difference, Diversity, and the Limits of Toleration', Political Theory, 18:3 (1990), pp. 361-391, at pp. 380-381.

${ }^{47}$ Saba Mahmood, 'Religious Reason and secular Affect: An Incommensurable Divide?' Critical Inquiry, 35 (2009), pp. 836-862, at pp. 845-849.
} 
incommensurable responses to the published caricatures of the Prophet Muhammed (appearing in Danish newspapers in 2005 and 2008) as between Muslims and Western Christians, with grievances of personal humiliation on the one side, and a rationalization of the purely emblematic role of religious iconography on the other. It is not merely symptomatic of a clash of religious ideologies, but of fundamentally different approaches to the social function of religion, which implicates both sociological and psychological experience: 'to interfere with the place of religion in society comes down to questioning the image that everyone forms of their collective identity but also of their intimate identity'. ${ }^{48}$

Indeed, such differences in religious identity may be traced back to a radical disjunction between the modern Christian subject, who manifests his or her faith as a matter of personal conscience and therefore private choice, and the more collective form of faith which to various degrees characterizes non-Western religions such as Islam, Judaism and Hinduism. While the former is compatible with the public-private divide promoted by the secular State, the latter presupposes a more conditional relation in which collective identity is embedded in personal identity, the two being impossible to disentangle. This difference has implications for the organization of social life, for the scope of religious freedom and personal liberty, and for the institutionalization of political equality. The secular State's role in managing religious life therefore cuts across both public and private spheres according to a historically-contingent political rationality: the privatization of religion, based on the increasingly introspective and autonomous nature of Christian faith, ensures that individuals exercise political agency as selfdetermining citizens separated from any parochial affiliations. Religious freedom in the Western sense is a product of this political rationality. The Protestant Christian idea of religion as internalized, based primordially on human conscience rather than the social form of religious

\footnotetext{
${ }^{48}$ Tzvetan Todorov, The Fear of Barbarians: Beyond the Clash of Civilizations, transl. Andrew Brown (Chicago: The University of Chicago Press, 2010), p. 151.
} 
community, largely informs the way in which freedom of religion is framed and applied. Mahmood suggests that the 'omission of any reference to the institutional conditions necessary for the preservation of collective aspects of religious life (such as religious schools, charities, and other associations)' in Article 18 of the Universal Declaration of Human Rights has particular adverse consequences for religious minorities who, 'without collective and communal institutions, remain vulnerable to losing their distinct forms of life and to assimilation to majoritarian norms' ${ }^{49}$ Moreover, the resulting tensions created by the different conceptions of religious faith between the dominant Christian and minority religions may in fact reinforce the public-private divide in a way that instigates cultural and political conflict. For example, the secular European State tends to force Muslims, many of whom already feel marginalized on the political and economic fronts, to retreat into their religious-cultural identity - always with the risk of promoting religious fundamentalism - even if it is an entirely constructed identity (which may be the case for those generations that have been Westernized). ${ }^{50}$ Thus, far from moving away from the political arena, as secular discourse ostensibly champions, this religious-cultural identity assumes enhanced political value as the marginalized voice against the authority of the State and the majoritarian interests it supports.

\section{The Politics of Inequality - Neutrality in the Public Sphere}

Speaking of Islamism as a politico-religious movement with 'internationalist' ambition, Tzvetan Todorov argues that it is at the same time undermined by a structural contradiction: its 'attempt to submit the political realm to the religious leads to the formation of a political movement, to which religion inevitably ends up being subjected'. ${ }^{51}$ We might suggest that the

\footnotetext{
${ }^{49}$ Saba Mahmood, Religious Difference in a Secular Age: A Minority Report (Princeton and Oxford: Princeton University Press, 2016), p. 49.

${ }^{50}$ Todorov, Fear of Barbarians, op. cit., p. 151.

${ }^{51}$ Ibid., p. 101.
} 
equally internationalist project of secularism suffers the same contradiction, albeit starting from the converse premises: namely, that in the attempt to restrict the public expression of religious values it politicizes religion, in particular, by making religion a polemical determinant for liberal-democratic discourse, and thereby renders it important for the legitimacy of political authority. This is especially the case with the secular ideal of a religiously neutral public space, and the scope for religious pluralism within that space. Secularism's focus on neutrality in the public sphere - and its corollary, the relegation of religion to private life - is one approach to formulating a legally-defined relationship between religion and democracy within the modern State, but it is by no means an unproblematic stratagem. The assumption that anything other than a secular order of public law and politics would be inconsistent with the democratic principles of freedom and equality confronts its own limitations. One limitation is the inherent instability of democracy as an institutional form - for example, with the paradox of democracy's potential to overthrow or undermine itself - which encourages recourse to external principles for regulating democratic deliberation; indeed, as Carlo Accetti suggests, 'the argument made by the Catholic Church through its critique of relativism is precisely that democracy needs to make reference to a transcendent criterion of legitimacy in order to be sustainable on its own terms' ${ }^{52}$ Another limitation is the impossibility of achieving absolute neutrality in the public arena, at least from the perspective of the political genealogy of the State. This is the case for two reasons: because the very notion of public space is a historical invention based on the liberal assumption that human existence can be separated into discrete parts that would align with the private and the public, an assumption that collapses in the face of multi-ethnic and multi-religious societies; and because religious neutrality is contingent on the particular relationship between the Christian subject (divided between his or her private

\footnotetext{
${ }^{52}$ Carlo Invernizzi Accetti, Relativism and Religion: Why Democratic Societies Do Not Need Moral Absolutes (New York: Columbia University Press, 2015), p. 15.
} 
religious faith and public persona as a citizen) and the State. In each case, the relativism implicit in religious freedom exposes the neutral public sphere as a contradictory manifestation of secular ideology. Let us consider some of the ways in which secularism's reliance on the construct of neutrality has effectively politicized and problematized religious difference.

\section{The precarious category of the 'minority'}

As Mahmood convincingly argues, it is precisely because the liberal State cannot maintain neutrality with regard to its national identity, which is rooted in the culture, language and religion of the majority population, that the advocacy of minority rights has taken hold in human rights discourse. In fact, it is fair to say that the concept of a 'minority' deserving of national and international protection became necessary only with the emergence of the nation State, to give effect to the tensions created among multiple ethnic and religious groups by virtue of territorial and political dislocation. However, there is an irresolvable tension in the concept of a minority: under the pretext of political equality a minority is entitled to equal treatment and equal access with the majority, while at the same time its religious, racial and ethnic difference 'poses an incipient threat to the identity of the nation that is grounded in the religious, linguistic, and cultural norms of the majority' ${ }^{53}$ The status of the minority religion remains indelibly linked to the project of nationalism; it is often the most potent basis for challenging the nationalist agenda, raising questions about the role of the dominant religion and its institutions in the legal and political framework of the State. At the same time, the minority's plight to achieve equality succumbs to a number of weaknesses. In the first place, the balance between the legal recognition of equality and the protection of minority difference cannot be formalized by reference to prerequisite criteria inherent to democratic pluralism, since no such criteria exist. Instead, the balance is worked out in accordance with culturally

\footnotetext{
${ }^{53}$ Mahmood, Religious Difference in a Secular Age, op. cit., p. 32.
} 
sensitive perceptions about the role of the particular minority in the polity and value judgments about its norms and practices, perceptions and judgments which inevitably change with time and context. Secondly, the minority is often caught up in the tension between the minimization of differences (generally reflected in policies towards assimilation) and the affirmation of differences in need of protection, which runs the risk of reifying the minority's exclusion by amplifying the differences. Thirdly, 'a minority's demand for redress requires that the group's subordination be thematized in the laws of the nation state (whether through affirmative action, proportionate representation, quotas, or special protections)', potentially encouraging the majoritarian accusation that the state is contravening its commitment to the equal treatment of all citizens. ${ }^{54} \mathrm{~A}$ further and broader problem lies with the question of precisely how to separate the nation (with its reproduction of majoritarian norms) from the State (representing equality and respect for minority difference), and indeed whether it is even possible to achieve this separation. Apart from the difficulty of defining the nation and its cultural attributes - bearing in mind also that there are always groups which live on the margins of society, and in the shadows of the majority, which nonetheless contribute a part to the national identity - the extent to which the State should reflect the particularity of the national identity in its laws when it comes at the detriment of the minority's religion raises a circular argument which cannot readily be resolved by any theory of State neutrality.

\section{The civilizing and educative significance of neutrality}

In his critique of secularism (laïcité) in the French State, Raphaël Liogier suggests that the principle of neutrality within laïcité does not suppose the strict separation of public authorities from religion on the basis of the latter's lack of competence; instead, it serves as an implicit

54 Ibid., p. 67. 
ideology justifying political interference in the religious field. ${ }^{55}$ This ideology of State intervention may be traced back to the French Republic of the nineteenth century, which invested itself with 'spiritual authority' to 'transmit universal values', and sowed the seeds for the rise of the anti-clerical movement that was instrumental in institutionalising laïcité in the form of the Separation of Churches and State Act 1905. Far from signifying the removal of the religious from the political, laïcité 'presupposes the denegation of the 'religious' nature' of the political intervention in religious affairs. ${ }^{56}$ This paradoxical element of neutrality may be considered its 'neutralising' function, which legitimizes the political qualification of religious beliefs and practices. At the same time, the secular State is also concerned with the 'naturalisation' of religion - as exemplified in the negotiations over the establishment of Muslim places of worship, and the authorization of religious practices within the State school system - which thereby permits Muslim individuals to have recourse to laïcité to found their right to express their Islamic identity. In spite of the complex and multidirectional operation of laïcité, the State's routine negotiation with Islam 'remains tributary to a fixed representation, both ideologically and organisationally centralised', ${ }^{57}$ what we may refer to as its civilising control or management of religion.

It is not without significance, then, that the aspect of the public sphere upon which the principle of laïcité has more often been brought to bear is that of education. The school, certainly in the case of the French republican model, may be understood as a transitional site between private existence and public space. This imposes contradictory imperatives: on the one hand, it must effectively detach individuals from their primary identities in order to facilitate their entrance into the political sphere of citizenship, ${ }^{58}$ on the other hand, it must 'give

\footnotetext{
${ }^{55}$ Raphaël Liogier, 'Laïcité on the Edge in France: Between the Theory of Church-State Separation and the Praxis of State-Church Confusion', Macquarie Law Journal, 9 (2009), pp. 25-45.

${ }^{56}$ Ibid., pp. 27-31.

${ }^{57}$ Ibid., p. 36.

58 'French pupils seem to be able to become citizens of the French republic only insofar as they leave their religion at home... pupils are thus erroneously being considered civil servants': Aeronout J.
} 
individuals the means to 'represent' their ideologies and belongings in political life, though without itself being political, i.e., without speaking the language of politics except indirectly and metaphorically (through history, literature, philosophy)' ${ }^{59}$ Whereas the school is not itself a direct representative of the State, its educative obligation is to 'carry out a neutralization' between the two non-neutral spaces, the private and the public. This places the school in an ambivalent zone, simultaneously a mechanism for promoting and nurturing State neutrality through the discourse of civic values, and the locus for the translation of religious difference into the egalitarian identity of citizenship and fundamental freedoms. The transformation of the private individual into the political citizen through the educational system cannot be divorced from political authority, nor immunized from the stakes invoked by a republican conception of neutrality, if only because there is a necessary tension 'between the authoritarian side of the teaching function and its democratic side, which consists at once in equality of opportunity' and 'in equal right to expression'. ${ }^{60}$ Liogier notes that the French State's denunciation ${ }^{61}$ of visible religious symbols as 'contrary to the mission of schools' reflects an insistence on interpreting the Muslim veil solely as an ideological representation of the inferiority of women, and the concomitant refusal to consider the variety of other plausible meanings. ${ }^{62}$ The civilising function of the educational system serves to delineate the problematic aspects of religion through a selective assessment of religious beliefs and practices based on criteria that remain largely opaque under the pretext of self-evidence. The circular logic of ascribing meaning to 'visible' religious practices by reference to certain civic qualities (such as gender equality) in

Nieuwenhuis, 'State and religion, a multidimensional relationship: Some comparative law remarks', I.CON, 10:1 (2012), pp. 153-174, at p. 173.

${ }^{59}$ Etienne Balibar, 'Dissonances within Laïcité', Constellations, 11:3 (2004), pp. 353-367, at p. 357.

${ }^{60}$ Ibid., p. 362.

${ }^{61}$ Via its specially appointed Commission, convened by Bernard Stasi, investigating the issue of the Muslim veil in schools (often referred to as the 'Stasi Commission').

${ }^{62}$ Liogier, op. cit., p. 38. 
order to present those practices as prejudicial to those same qualities is secularism's polemical trompe l'oeil, so to speak.

\section{Gender inequality as a public order concern}

It is clear that the idea of neutrality in the public sphere has rarely been limited to the principle of State indifference towards religion, not merely because, as we have already noted, secularism has generally invoked the State's right to regulate or manage religion, at least in its visible manifestations, but also because the requirements of a democratic society endue the public sphere with certain values, principal among them being gender equality. In this regard, Etienne Balibar alerts us to a contradiction between two emancipatory claims concerning the postcolonial liberation of women: the claim against ethnic discrimination and cultural racism associated with the hegemony of imperial nations, and that against the subordination, violence and denial of equality towards women. It is not a contradiction that can be dissolved facilely, either through an approach that argues for the natural convergence of the two claims, or through one "which presents the institutions and values of the "West" as the model and vehicle of women's emancipation everywhere' ${ }^{63}$ The tendency in secular discourse has been to subsume the complex and arguably substratal ethnic-cultural claim within the superficially more transparent gender inequality claim. The result is to present religious particularity as an archaic and antagonistic challenge to the democratic principles of gender equality and freedom of choice. Of course, we can agree with Balibar that the most patent victims of this problem are young Muslim girls, effectively caught between two competing sites of male authority claiming control over their decision-making and lives, 'one on behalf of patriarchal authority wrapped up in religion, the other on behalf of national authority wrapped up in secularism'. ${ }^{64}$ The irony,

\footnotetext{
${ }^{63}$ Balibar, op. cit., p. 359.

${ }^{64}$ Ibid., p. 359.
} 
however, is that it is the 'voluntary veil' manifested in public rather than the 'imposed veil' within the private sphere of family life that has been the principal subject of the gender inequality claim. ${ }^{65}$ The concern over the voluntary veil, which ostensibly is considered the more dangerous from the perspective of public order, belies the indifference towards the potential subordination of women in private life, as much as it evades interest in alternative conceptions of personal freedom within the framework of religious belief. It reflects the position that Muslim women need to be protected in spite of their beliefs and desire for modesty, in effect that they need to be protected against themselves, since their ideas have been adopted under the influence of a patriarchal religion, even perhaps a product of psychological violence, most likely from a young age when they lacked the maturity and moral capacity to consent. This of course raises the justifiable question of the circumstantial preconditions for voluntariness and free choice in a given society. Nonetheless, the basis for this irony becomes clearer when we observe the facility with which gender equality and secularism collude in juridical discourse.

The argument for gender equality that is often raised in the context of restrictions on the public display of religious symbols is premised upon the assumption that Islamic prescriptions for wearing the veil are a patent form of discrimination against women, an assumption which strictly speaking infects both public and private spaces, and in reality more pervasively the latter. However, in the human rights language of legitimacy of State interference with freedom to manifest religion, the argument for gender equality is conflated with broader concerns about the democratic requirements in the public sphere. In 'veiling' cases before the European Court of Human Rights, governmental restrictions on religious attire in schools have been explicitly sanctioned on the basis that it is 'difficult to reconcile the wearing of an Islamic headscarf with the message of tolerance, respect for others and, above

\footnotetext{
${ }^{65}$ Liogier, op. cit., p. 40.
} 
all, equality and non-discrimination that all teachers in a democratic society must convey to their pupils', ${ }^{66}$ and that the values of pluralism and equality before the law of men and women justify preserving the secular nature of the State. ${ }^{67}$ While the two legal justifications relied upon are theoretically distinct - one concerned with the preservation of secularism (in the language of 'public order'), the other with preventing gender inequality (in the language of 'protecting the rights of others') - the conceptual nexus that is implied, though never fully explained, within the jurisprudence amplifies the significance of the public sphere (and its import of democratic norms) for managing religious difference. On this count, it is true that there is a consistent thread within human rights law that responds differentially towards conduct in the public sphere compared with the private sphere, with freedom of expression and nondiscrimination being exemplary cases. However, the issue we have raised regarding how gender inequality is treated in the respective spheres within secular discourse is less a question of differences in significance between public and private discrimination than of the conceptual artifice involved in justifying restrictions of the public display of religious symbols based on the need to protect against the unequal treatment of women - especially when 'voluntarily' manifested - as mandated by the requirements of a democratic society. Moreover, the theoretical leap involved in this equation is rarely subjected to judicial scrutiny, let alone explained in policy determinations, in the context of negotiating between religious and secular claims.

\section{Understanding the Effects of Secularism in Human Rights Discourse - A Way}

\section{Through}

\footnotetext{
${ }^{66}$ Lucia Dahlab v. Switzerland, Eur. Ct. H.R. (2n ${ }^{\text {nd }}$ Sect.), 15 February 2001 (Appl. No. 42393/98), no paragraph noted.

${ }^{67}$ Leyla Sahin v. Turkey, Eur. Ct. H.R. (GC), 10 November 2005 (Appl. No. 44774/98), para. 116.
} 
We can synthesize the above analysis by suggesting a number of arguments that are borne out in the literature.

Firstly, the secular State has never sought to eradicate religious belief and expression from society, but to set the terms upon which its visibility is consistent with certain liberaldemocratic principles, themselves influenced by a theological-political paradigm of government.

Secondly, the relationship between secular ideology and religious freedom is premised upon the assumption that it is possible to separate the religious from the non-theistic aspects of society, whereas the religious has developed historically with the State form and is intertwined with its political, legal, economic and cultural institutions. A consequence of the secularreligious binary is that it obscures the variety of contributors to political and social conflicts, and does not faithfully account for the intersection of religious difference in those conflicts.

Thirdly, the relegation of religion to the private sphere, consistent with Christianity's internalization of the religious experience through individual conscience, creates a dissonant social environment for religions that are oriented towards communal and political expression, heightening the tensions between the secular State and minority religions.

Fourthly, a fundamental problem with secularism's focus on neutrality in the public sphere is its tendency to neutralize minority religions in accordance with a civilising Western paradigm. The fact that the public sphere is a historical invention associated with a particular conception of the individual's relationship to society and the State reinforces an asymmetrical understanding of the role of religion in the lives of different religious groups. Moreover, policing or managing religions in the name of secularism amplifies the importance of religion for individual and collective identity, creating the individual as a religious subject potentially in conflict with political subjectivity. 
Critical scrutiny of the dictating role of secular discourse for religious freedom assists in understanding the antinomies associated with the attempt to institute religious equality within a secular political system. The question of what is left of religious freedom as a human right once these antinomies are accounted for nevertheless remains a viable and urgent concern. There have been various attempts to address this concern and rethink the relationship between religious freedom and the liberal-democratic model of secularism. One such attempt is that of Accetti, who presents a defence of relativism premised on the assumption that conflicts between values are an inherent part of a democratic society. Eschewing the Catholic Church's conception of freedom as tied to an 'overarching system of values organized by a unitary logic', he suggests a pluralistic understanding of freedom, which need not be compatible with all human values but can operate in a formal mode and without a priori concrete content. Through a relativist conception of democracy he advocates for a middle path between a secularism that constrains religious expression in the public sphere and a post-secularism that accords religion a privileged role within the political process. ${ }^{68}$ The sleight of hand involved in this alternative form of secularism is to anchor it in the philosophical foundation for democracy, whereas religious beliefs are to be treated as 'second-order' knowledge based on prior categories and premises which cannot serve to justify political authority in any absolute sense. The concession to majoritarian interests is the acknowledgment that since laws that are passed should in principle reflect the views of the individuals within the polity, the religious values of a majority of religious citizens will accordingly influence those laws, as would the secular values of an irreligious majority. To the objection that this conception of secularism is not neutral among all possible religious views since some religions may be categorically opposed to the very concept of relativism, he stresses that it misses the point of the overall conception of democracy he is defending, which does not aim to be absolutely neutral but rather 'to give expression to a

${ }^{68}$ Accetti, op. cit., pp. 121-122. 
specific set of substantive values that are assumed to follow logically from the assumption of a form of philosophical relativism'; thus, 'religious views that are unwilling to recognize their own relativity and therefore engage in a reflexive process of confrontation with others based on the principles of freedom and equality have no place within a democratic society'. ${ }^{69}$ Accetti's approach does to some extent avoid the problems associated with the neo-Kantian rationalist philosophy of Habermas, which, in tying the legitimacy of democracy to the principle of communicative rationality, remains committed to the promotion of substantive moral values to which conflicting religious views must necessarily give way. However, his purely formal notion of democratic relativism - inclined 'toward a maximal inclusion of all possible views and opinions within the political process'- confronts the dilemma of whether to remain open and hospitable to religious systems that challenge this inclusivity, or at least that are less relativistic than modern Western Christianity has proved to be. It is not clear that this vision of secularism successfully evades the reintroduction of majoritarian norms via the notion of democratic consensus. In fact, it is not difficult to see how religious freedom might be held captive to certain interpretations of other rights, such as of freedom of expression and freedom from discrimination, and certain governmental doctrines, such as public order and the secular market place, which are deemed to be compatible with the reflexive relativism required of all religious systems in this model of democratic society.

A similar concern arises with Cècile Laborde's critique of religion as a politico-legal category in Liberalism's Religion. Laborde makes a salient observation as to the fact that neutrality and separation cannot be reduced to a simple contradiction, given that liberal neutrality can refer either to the justification of specific arrangements or to the principle of equal treatment of different conceptions of the good and ways of life. ${ }^{70}$ She correspondingly

\footnotetext{
${ }^{69}$ Ibid., pp. 218-219.

${ }^{70}$ Cècile Laborde, Liberalism's Religion (Cambridge MA \& London: Harvard University Press, 2017), pp. 37-38.
} 
offers a novel approach to reconceptualising the liberal order's relationship with religion, based principally on the disaggregation of religion into 'a plurality of normative dimensions,' which allows religion to be brought within a liberal-egalitarian framework. However, her analysis remains tied to a conception of religion as merely one of the many - and equally justifiable conceptions of the good, or ways of life, that make up the pluralism of contemporary societies. ${ }^{71}$ In effect, her programme for the protection of religious freedom within a liberal framework is devised around an egalitarian vision of the role of religion in society. The operating principle is the requirement for a liberal state to remain neutral, not only as between religions, but also as between 'almost all aspects of its citizens' conceptions of the good, whether these are spiritual or secular. ${ }^{72}$ As a constructed model for how a modern liberal order can coexist with the protection of religious freedom, this approach has much to commend itself. At the same time, the tendency to strip religion of its historical particularity presents a significant limitation. For many religious believers, at least those adhering to Judeo-Christian and other messianic faiths, religion is never just another good or way of life; it is the singularly valid way of life. Moreover, for such adherents, religion is rarely understood in relative terms but instead operates wholistically and universally, leaving cultural and social differences as problems to be resolved or conditions to be assimilated. On Laborde's analysis, an egalitarian liberal approach to the protection of religious beliefs can only work if individual believers relinquish their parochial and often incompatible religious worldviews and accept that their respective belief systems are merely one iteration of the various spiritual and secular conceptions of the good. Looking beyond its aspirational qualities, however, it is not obvious how this approach can account for the range of incommensurable religious convictions and lifestyles, or at least

\footnotetext{
${ }^{71}$ Ibid., p. 32.

${ }^{72}$ Ibid., p. 27.
} 
not without the cost of the liberal state once again intervening in the construction of religion and religious identity.

Another approach would be to seek an ethical problematization of religious freedom beyond State agency. In the epilogue to her study on religious difference, Mahmood notes the importance of scrutinising the particular form religious inequality takes at a given time and place, accepting that religious equality is not merely a concern of the State but also represents the aspirations and struggles of ordinary people. Moreover, it is a principle that at different times and for diverse groups may come into conflict with other ideals and demands, such as those grounded in gender, class, race, or ethnicity, which entails that it be constantly balanced against other political necessities, interests and rights. As an aspiration that is 'embedded in the historically grounded sensibilities of the different communities that constitute the social' - and we may note here that there is unlikely to be a uniform understanding among different religious communities as to what constitutes religious equality and religious freedom, let alone their application where different religious and social sensibilities collide - it is "not reducible to the actions and policies of the State or its legal edicts'. ${ }^{73}$ The possibility opened up by this line of thinking is to imagine a politics of religious difference that does not rely upon the ideal and fallacy of the State as a neutral arbiter of religious and secular co-existence. At the same time, the challenge for a human rights response to religious difference is to understand the stakes involved in the secular approach to political identity and social relations, which extend beyond the organization of the State form, influencing the cultural as much as the strictly political landscape, without losing sight of the fact that the State remains a crucial player in the transmission of religious freedom. Simply attempting to ignore or sidestep the religionsecularism debate is unlikely to be fruitful, if only because in the modern liberal-democratic State secularism has been defined by religion, while, under various social and political

\footnotetext{
${ }^{73}$ Mahmood, Religious Difference in a Secular Age, op. cit., pp. 210-211.
} 
pressures (including changes in democratic participation, nationalist agendas and migration), religion is constantly defined by a secular approach to governance, citizenship and public order. This co-dependent relationship makes religious freedom a contested notion, calling into question both the terms of argument utilized in human rights law - whether for the realization or restriction of the freedom - as well as how we understand the place of religious belief and expression in a democratic society.

In Beyond Religious Freedom Elizabeth Hurd addresses this very question of the contested notion of religious freedom as a mode of governance of social difference, elucidating three principal concerns: that the discourse of religious freedom defines individuals and groups in religious or sectarian terms at the expense of other affinities, whether political, historical, geographical, socioeconomic, pertaining to kinship, and so on; that religions are effectively shaped by political authorities through legal recognition, consecrating 'groups as discrete faith communities with identifiable leaders and neatly bounded orthodoxies', which further marginalizes sectarian or minority religious groups that are excluded from the institutionallyrecognised identity; and, that the right to religious freedom privileges subjective belief as the principal characteristic of religion, in the process failing to protect other forms of religious belonging and expression. ${ }^{74}$ Thus, she postulates, the 'global promotion of religious rights and freedoms, like sectarianism, is a discourse of expert religion and governed religion, defined and authorized by those in power', producing rather than softening religious divisions and the resulting social frictions. ${ }^{75}$ To the extent that it is possible to conceive of religion beyond what has been sanctioned by political and religious authorities, a critical awareness of the fact that the selective governance of religious difference under both national and international laws does not exhaust the lived religious experiences and relations among individuals and groups should

\footnotetext{
${ }^{74}$ Elizabeth Shakman Hurd, Beyond Religious Freedom: the New Global politics of Religion (Princeton and Oxford: Princeton University Press, 2015), pp. 38-40.

${ }^{75}$ Ibid., p. 41.
} 
at least bring some clarity to the understanding of the deficiencies in the current regime of human rights protection, even if it offers no tangible solutions.

If we accept, as a number of theorists have argued, ${ }^{76}$ that the political and sociallytransformative power of human rights is effectively stifled by its pursuit of consensus, the question left to us is whether there is scope for human rights law to meaningfully protect religious pluralism? Two insights, in particular, may suggest a way forward. The first pertains to resolving the tension between the State's homogenous identity and the challenges posed by religious pluralism. Talal Asad observes that hostility to the presence of religion in the public sphere is 'a reflection of the fact that the concept and practice of religion - as well as of politics and ethics - are in the process of being formed or radically reformed in modern liberal society', while the State remains committed to a 'singular personality for itself in the exercise of sovereignty'. ${ }^{77}$ Whereas human rights law has the capacity to interrogate the dominant identity associated with the State apparatus, the presuppositions built into the Conventional structure of freedom of religion in international and regional laws, in particular, the possibility of limitations based on justifications concerned with various 'public' interests, limits the extent to which it can give effect to cultural heterogeneity. What is required as part of this awareness of the reformation of religion in modern liberal society is a more acute understanding of the place of religious belief in a political system that has institutionalized the separation of the religious and the political under the name of secularism. This would include a more expansive and heterogeneous interpretation of the public space, one that reflects the importance of religious freedom to the make-up of the social collective, encouraging both respect for

\footnotetext{
${ }^{76}$ See, for example, Costas Douzinas, Human Rights and Empire: The Political Philosophy of Cosmopolitanism (Abingdon: Routledge-Cavendish, 2007), and Michael Ignatieff, Human Rights as Politics and Idolatry (Princeton, New Jersey: Princeton University Press, 2001).

77 Tala Asad, 'Thinking About Tradition, religion, and Politics in Egypt Today', Critical Enquiry, 42 (2015), pp. 166-214, at pp. 203-205.
} 
differences and the potentiality of acculturation, and which restricts the imposition of secular principles such as public neutrality upon the social field.

The second concerns the function of human rights in attenuating the limitations of democratic processes. It has been suggested that the pessimism regarding the possibility of the supposed crisis between Muslim identity and liberal values in Europe being resolved through the conventional democratic processes of representation and negotiation has resulted in the crisis being seen as 'an exception to the normal functioning of politics' and leading to a "programme of assimilation of the required "shared values", ${ }^{78}$ The risk for a human rights system that is treated as the handmaiden to democratic consensus is its complicity in this programme of assimilation. This has been played out in various contexts where conflicts between 'national values' and the manifestation of minority religious beliefs have been subjected to a human rights' analysis which privileges a homogenous conception of public order and the depoliticization of religious difference through the public-private divide. By the same token, human rights law (both supra-national and constitutional) may also be seen as an 'exceptional' response to social conflicts which 'conventional' democratic processes are unable to quell or indeed which they often exacerbate. Endorsing Clause Lefort's argument that modern democracy replaces the notion of a regime governed by laws, as a legitimate power, with the notion of 'a regime founded upon the legitimacy of a debate as to what is legitimate and what is illegitimate - a debate which is necessarily without any guarantor and without any end ${ }^{79}$ - we can appreciate that human rights have a strategic role precisely in the space where democratic consensus is in dispute, its dissensus. In this sense, human rights law, as a product of liberal-democratic society and at the same time a vehicle for the critique of

\footnotetext{
${ }^{78}$ Arun Kundnani, 'Multiculturalism and its discontents: left, Right and liberal', European Journal of Cultural Studies, 15:2 (2012), pp. 155-166, at p. 158.

${ }^{79}$ Claude Lefort, Democracy and Political Theory, transl. David Macey (Cambridge UK: Polity Press, 1988), p. 39.
} 
liberal values, has potential to mediate between different democratic principles (including the civic values of free expression, association and equality, as well as freedom of religion) and to determine the negotiable and necessarily tentative balance of secular politics and religious sensitivity in modern multicultural societies. 